\title{
A PRACTICAL DISCOURSE ON SOME PRINCIPLES OF HYMN-SINGING.
}

WHAT St. Augustin says of the emotion which he felt on hearing the music in the Portian basilica at Milan in the year $3^{86}$ has always seemed to me a good illustration of the relativity of musical expression; I mean how much more its ethical significance depends on the musical experience of the hearer, than on any special accomplishment or intrinsic development of the art. Knowing of what kind that music must have been and how few resources of expression it can have had,- - being rudimental in form, without suggestion of harmony, and in its performance unskilful, its probably nasal voice-production unmodified by any accompaniment, -one marvels at his description,

'What tears I shed at Thy hymns and canticles, how acutely was my soul stirred by the voices and sweet music of Thy Church! As those voices entered my ears, truth distilled in my heart, and thence divine affection welled up in a flood, in tears o'erflowing, and happy was $I$ in those tears '.'

St Augustin appears to have witnessed the beginnings of the great music of the Western Church. It was the year of his baptism when, he tells us, singing was introduced at Milan to cheer the Catholics who had shut themselves up in the basilica with their bishop, to defend him from the imperial violence:

'It was then instituted that psalms and hymns should be sung, after the manner of the Eastern Churches, lest the folk in the weariness of their grief should altogether lose heart : and from that day to this the custom has been retained; many, nay, nearly all Thy flocks, in all regions of the world, following the example "?

What great emotional power St. Augustin attributed to 1 Confuses ix 6.

I Itid. ix $\%$. 
ecclesiastical music, and of what importance he thought it, may be seen in the tenth book of the Confessions: he is there examining himself under the heads of the senses, and after the sense of smell, his chapter on the sense of hearing is as follows:-

' The lust of the ears entangled and enslaved me more firmly, but Thou hast loosened and set me free. But even now I confess that I do yield a very little to the beauty of those sounds which are animated by Thy eloquence, when sung with a sweet and practised roice; not, indeed, so far that I am limed and cannot fly off at pleasure ${ }^{1}$ : and yield though I do, yet these sweet sounds, joined with the divine words which are their life, cannot be admitted to my heart save to a place of some dignity, and I hesitate to give them one as lofty as their claim ${ }^{2}$.

For sometimes I seem to myself to be allowing them undue honour, when I feel that our minds are really moved to a warmer devotion and more ardent piety by the holy words themselves when they are so sung than when they are not so sung; and when I recognize that all the various moods of our spirit have their proper tones in speech and song, by which they are, through I know not what secret familiarity, excited. But the mere sensuous delight, to which it is not fitting to resign the mind to be -enervated thereby, often deceives me, whenever (that is) the delight of the senses does not so accompany the reason as to be cheerfully in submission thereto, but, having been admitted only for reason's sake, then even attempts to go before and to lead. Thus I sin without knowing, but afterwards I know.

Then awbile, from too immoderate caution against this deception, I err on the side of too great severity; and sometimes go so far as to wish that all the melody of the sweet chants which are used in the Davidian psalter were utterly banished from my ears, and from the ears of the Church; and that way seems to me safer which I remember often to have heard told of Athanasius, archbishop of Alexandria, that he would have the lector of the psalm intone it with but a slight modulation of voice, so as to be more like one reading than one singing. And yet, when I remember my tears, which I shed at the hearing of the song of Thy Church in the first days of my recovered faith, and that now I still feel the same emotion, and am moved not by the singing but by what is sung, when it is sung with a liquid voice and in the most fitting "modulation," then (I say) I acknowledge again the great utility of the institution.

Thus I fluctuate between the peril of sensuous pleasure and the proof

1 This is perhaps rather a quality proper to the sensation.

1 'Et vix eis praebeo congruentem [locum],' which might only mean 'I cannot find the right place for them.' 
of wholesomeness, and am more inclined (though I would not offer an irrevocable judgement) to approve of the use of singing in the Church, that, by the pleasure of the ear, weaker minds may rise to the emotion of piety. Yet when it happens to me to be more moved by the music than by the words that are sung I confess that I have sinned (poenaliter peccare), and it is then that I would rather not hear the singer ${ }^{1 .}$

What would St. Augustin have said could he have heard Mozart's Requiem, or been present at some Roman Catholic cathedral where an eighteenth-century mass was performed, a woman hired from the Opera-House whooping the Benedictus from the western gallery?

It is possible that such music would not have had any ethical significance to him, bad or good. Augustin lived before what we reckon the very beginnings of modern music, with nothing to entice and delight his ears in the choir but the simplest ecclesiastical chant and hymn-tune sung in unison. We are accustomed to an almost over-elaborated art, which, having won powers of expression in all directions, has so squandered them that they are of little value: and we may confidently say that the emotional power of our church music is not so great as that described by him 1,500 years ago. In fact if we feel at all out of sympathy with Augustin's words, it is because he seems to over-estimate the danger of the emotion ${ }^{2}$.

There is something very strange and surprising in this state of things, this contrast between the primitive Church with its few simple melodies that ravished the educated hearer, and our own full-blown institution with its hymn-book of some 600 tunes, which when it is opened fills the sensitive worshipper with dismay, so that there are persons who would rather not go inside a church than subject themselves to the trial.

What is the matter? What is it that is wrong with our hymnody? Even where there is not such rooted disgust as I have implied, there is a growing conviction that some reform is needed in words or music or both.

Assuming that the chief blame lies with the music (as, I think, might easily be proved), I propose to discuss the question of the

1 Conface $\times 33$

' St. Augustin does not allow that a vague emotion can be religious; it must be directed. Few would agree to this. 
music of our hymnody, and I shall proceed on the basis of St. Augustin's principles: I am sure that they would be endorsed by any pious church-goer who had considered the subject, and they may be fairly formulated thus, The music must express the words or sense: it should not attract too much attention to itself: it should be dignified: and its reason and use is to heighten religious emotion.

One point calls for distinction: Augustin speaks of his emotion on hearing the hymns and canticles; he writes as if he had had no more thought of taking part in the music himself, than we have of joining in the anthem at a cathedral; and this might lead to a misunderstanding; for there is no doubt that these hymns were sung by the people: the story is that the very soldiers who were sent to blockade the basilica, happening to be themselves catholics, joined their voices in the stanzas which St. Ambrose had specially composed to disconcert the Arian enemy.

The ecstasy of listening to music, and the enthusiasm of a crowd who are all singing or shouting the same hymn or song are emotions of quite different nature and value. Now, neglecting the rare conditions under which these emotions may be combined, we shall, as we are speaking of hymns, be concerned chiefly with the latter kind, for all will agree that hymns are that part of the Church music in which it is most desirable that the congregation should join: and I believe that there would be less difference in pra, :e if it were at all easy to obtain good congregational singing, or even anything that is worthy of the name. It seems perhaps a pity that nature should have arranged that where the people are musical (as Augustin appears to have been) they would rather listen, and where they are unmusical they would all rather sing.

Speaking therefore of congregational hymn-singing, and conceding, as I think we must, that the essential use of such music is to heighten emotion, then, this emotional quality being the sine qua non (the music being of no use without it), it follows that it is the primary consideration. If we are to have music at all, it must be such as will raise or heighten emotion; and to define this we must ask, Whose emotion? and What kind of emotion? 
Let us take this latter question first, and inquire what emotions it is usual, proper, or possible to express by congregational singing of hymns. William Law; in his Serious Call, has an interesting, I may say amusing, chapter on the duty of all to sing, whether they have any turn or inclination for it or no. All should sing, he says, even though they dislike doing so, and I think that what he affirms of private devotion applies with greater force to public worship. It should satisfy the most ardent advocate of congregational singing, and it goes certainly to the root of the matter.

'It is so right and beneficial to devotion, has so much effect upon our hearts, that it may be insisted on as a common rule for all persons ... for singing is as much the proper use of a psalm as devout supplication is the proper use of a form of prayer : and a psalm only read is very much like a prayer that is only looked over.... If you were to tell a person that has such a song, that he need not sing it, that it was sufficient to peruse it, he would wonder what you meant, ... as if you were to tell him that he should only look at his food, to see whether it was good, but need not eat it. . . You will perhaps say that singing is a particular talent, that belongs only to particular people, and that you have neither voice nor ear for music.

If you had said that singing is a general talent, and that people differ in that as they do in all other things, you had said something much truer.

For how vastly people differ in the talent of thinking, which is not only common to all men, but seems to be the very essence of human nature : . . . Yet no one desires to be excused from thought because he has not this talent in any fine degree....

If a person were to forbear praying because he had an odd tone in his voice, he would have as good an excuse as he that forbears from singing psalms because he has but little management of his voice....

These songs make a sense (of) delight in God; they awaken holy devotion : they teach how to ask : they kindle a holy flame....

Singing is the natural effect of Joy in the heart ... and it is also the natural means of raising EMOTIONS or JOY in the mind : such JOY AND THANXrulNess to God as is the highest perfection of a divine and holy life.'

Now though I cannot feel the force of all Law's arguments nor easily bring myself to believe that a person who dislikes singing, and has no ear for music, will readily find any comfortable assistance to his private devotion from making efforts to hit 
off the notes of the scale; yet I feel that Law's position is in the main sound, and that he has correctly specified the emotion most proper to that kind of uncultured singing which he describes: and though congregational psalm-singing necessarily involves a greater musical capacity than that assumed in Law's extreme case, and may therefore have a wider field, yet we may begin by laying down that JOY, PRAISE, and THANRSGIVING give us the first main head of what is proper to be expressed, and we may extend this head by adding ADORATION and perhaps the involved emotions of AWE and PEACE and even the attitude of CONTEMPLATION.

In such a subject as the classification of emotions as they may be expressed by music of one kind or another, it is plainly impossible to make any definite tabulation with which all would agree. The very names of the emotions will, to different minds, call up different associations of feeling. If any agreement could be arrived at, it would be at the expense of distinction; and all that I can expect is to have my distinctions understood, and in the main agreed with. And as I am most ready to grant to the reader his right to a different opinion on any detail, I beg of him the same toleration, and that he will rather try to follow my meaning than dwell on discrepancies which may be due to a fault of expression, or to a difference of meaning which he and I may attach to the same word.

With this apology in preamble, I will attempt to make some classification of emotions as they seem to me to be the possible basis for musical expression in congregational singing.

We have already one class: I would add a second, to include all the hymns which exhibit the simple attitude of PRAYER.

A third class I would put under the head of FAITH. Examples of this class will no doubt often cross with those of the first class, but they will specify themselves as CELEBRATIONS of events of various COMMEMORATION, introducing a distinct form, namely NARRATION, which is a very proper and effective form for general praise.

Also this section will include all the hymns of BROTHERHOOD and FELLOWSHIP, and of SPIRITUAL CONFLICT, with the correlative invitatory and exhortatory' songs, as modified by what will be said later. 
Also, lastly, under this same head of Faith, the DOCTRINAL hymns, and professions of creed whether sectarian or otherwise, which, if the definition be taken widely, make a large and popular class, well exemplified by the German hymns of the Reformation, or by those of our Wesleyan revival: strong with the united feeling of a small body, asserting itself in the face of opposition: concerning which we will not speak further, except to recall the fact that this kind of enthusiasm was not absent from the causes which first introduced hymns into the Western Church.

I believe that this is a pretty full list of all the attitudes of mind that can be properly expressed by congregational singing; and if we turn to other emotions which are made the subject of church hymns, we shall, I think, see that they are all of them liable to suffer damage by being entrusted to the rough handling of general vociferation.

Such will be all hymns of DIVINE AFFECTION and YEARNING; all LAMENTS and CONSOLATIONS; all descriptions of spiritual conditions which imply personal experience and feeling, as ABASEMENT, HUMILIATION, CONTRITION, REPENTANCE, RESIGNATION, SELF-DEVOTION, CONVICTION, and SATISFACTION.

Here I feel that many readers will be inclined to dissent from what I say, and as I shall not again recur to Law, I should like, in order to show my meaning, to call up his extreme example of an unmusical person singing in private devotion. If one pictures such a case as he supposes, is it not clear, whether one imagines oneself the actor or the unwilling auditor, that while such an exhibition of joy might perhaps pass, yet a similar incompetent attempt to express any of the last-named emotions would be only ridiculous? But between this single worshipper and the congregation the incompetence seems to me only a question of degree; while in the far more considerable respect of the sincerity of the feeling in the hearts of those expressing it, Law's singer has every advantage; indeed no objection on this score can be raised to him. But now suppose for a moment that he has not the emotion at heart corresponding to his attempt at song, and I think the differentiation of motives for congregational singing will seem justifiable.

All these last-named emotions,-which I have taken from congregational hymn-books,- and I suppose there may be more 
of them,-call for delicacy of treatment. A Lamentation, for instance, which might seem at first sight as if it would gain force by volume, will, if it is realistic or clumsy, become unmanly, almost so as to be ridiculous, and certainly depressing to the spirit rather than purifying. In fact while many of the subjects require beautiful expression, they are also more properly used when offered as inspiring ideals; and to assume them to be of common attainment or experience is to degrade them from their supreme sanctity. But in thus ruling them unfit for general singing one must distinguish large miscellaneous congregations from small united bodies, in which a more intimate emotion may be natural: and as there is no exact line of distinction here, so there is no objection to the occasional and partial intrusion of some of these more intimate subjects into congregational hymns.

To this first question then, as to what emotions are fit to be expressed by congregational music, the answer appears to be that the more general the singing, the more general and simple should be the emotion; and that the universally fitting themes are those of simple praise, prayer, or faith : and we might inquire whether one fault of our modern hymn-books may not be their attempt to supply congregational music to unfitting themes.

To the next question, Whose emotion is this congregational music to excite or heighten? the answer is plain: It is the average man, or one rather below the average, the uneducated, as St. Augustin says the weaker, mind; and that in England is, at least artistically, a narrow mind and a vulgar being. And it may of course be alleged that the music in our hymn-books which is intolerable to the more sensitive minds was not put there for them, but would justify itself in.its supposed fitness for the lower classes. 'What use,' the pastor would say to one who, on the ground of tradition advocated the employment of the old plain-song and the Ambrosian melodies, "What use to seek to attract such people as those in my cure with the ancient outlandish and stiff melodies that pleased folk a thousand years ago, and which I cannot pretend to like myself?' Or if his friend is a modern musician, who is urging him to have nothing in his church but what would satisfy the highest artistic sense of the day, his answer is the same: he will tell you that it would be 
casting pearls before swine; and that unless the music is 'tuney' and 'catchy' the people will not take to it And we cannot hastily dismiss these practical objections. The very Ambrosian music which is now so strange to modern ears was doubtless, when St. Ambrose introduced it, much akin to the secular music of the day, if it was not directly borrowed from it: and the history of hymn-music is a history of the adaptations of profane successes in the art to the uses of the Church. Nor do I see that it can ever be otherwise, for the highest music demands a supernatural material; so that it would seem an equal folly for musicians to neglect the unique opportunity which religion offers them, and for religion to refuse the best productions of human art. And we must also remember that the art of the time, whether it be bad or good, has a much more living relation to the generation which is producing it, and exerts a more powerful influence upon it, than the art of any time that is past and gone. It is the same in all aspects of life: it is the book of the day, the hero or statesman of the hour, the newest hope, the latest flash of scientific light, which attracts the people. And it must be, on the face of it, true that any artist who becomes widely popular must have hit off, 'I know not by what secret familiarity,' the exact fashion or caprice of the current taste of his own generation.

And this is so true that it must be admitted that it is not always the uneducated man only whose taste is hit off. In the obituary notices of such men as Gladstone and Tennyson the gossip will inform us, rightly or wrongly, that their 'favourite hymn " "was, not one of the great masterpieces of the world,which, alas, it is only too likely that in their long lives they never heard,- -but some tune of the day: as if in the minds of men whose lives appealed strongly to their age there must be something delicately responsive to the exact ripple of the common taste and fashion of their generation.

All this makes a strong case: and it would seem, since our hymn-music is to stir the emotions of the vulgar, that it must itself be both vulgar and modern; and that, in the interest of

1 I assume 'favourite bymn' to mean a sung bymn. The interest of the record must lie in its being of a heightened emotion of the same kind es that described by St. Augustin in his own case, What tears $I$ shed, \&c. 
the weaker mind, we must renounce all ancient tradition and the maxims of art, in order to be in touch with the music-halls.

This is impossibly absurd; and unless there is some flaw in our argument, the fault must lie in the premisses; we have omitted some necessary qualification.

The qualification which we neglected is this, that the music must be dignified, and suitable to the meaning; and we should only have wasted words in ignoring what we knew all along, if we had not, by so doing, brought this qualification into its vital prominence, and at the same time exposed the position of those who neglect it, and the real reason of the mean condition of our church music.

The use of undignified music for sacred purposes may perhaps be justified in exceptional cases, which must be left to the judgement of those who consider all things lawful that they may save some. But if from the mission service this licence should creep into the special service, and then invade every act of public worship, it must be met with an edict of unscrupulous exclusion. Not that it can be truly described as thus having crept in in our time. It is always creeping, it has flourished in special habitats for four or five hundred years, and before then there is the history of Palestrina's great reform of like abuses. If in our time in England we differ in any respect for the worse, it is rather in the universal prevalence of a mild form of the degradation, which is perbaps more degrading than the occasional exceptional abuses of a more flagrant kind, which cannot hide their scandal but bring their own condemnation.

There is indeed no extreme from which this abuse has shrunk; perhaps the worst form of it is the setting of sacred hymns to popular airs, which are associated in the minds of the singers with secular, or even comic and amatory words ${ }^{1}$ : of which it is impossible to give examples, because the extreme instances are blasphemies unfit to be quoted; and it is only these which

1 It was not an uncommon practice on the Continent (say from 1540 to 1840 ), to print books of hymns to be sung to the current secular airs; and the names or first lines of these airs were set above the hymn-words as the musical direction. M. Douen, in his Climmot Harat at lo psantier Hugumot, vol i, ch. oa, has given an account of some of these books; and any one who wishes to follow this branch of the subject may read his chapter. He does not notice the Later Italian Laxde Spiritwali, which might have supplied incredible monsters to his museum.

VOL. I. 
could convey an adequate idea of the licence ${ }^{1}$. The essence of the practice appears to be the production of a familiar excitement, with the intention of diverting it into a religious channel.

But, even in the absence of secular or profane association, congregational singing, when provoked by undignified music, such as may be found in plenty in our modern hymn-books, may be maintained without the presence of religious feeling, out of mere high spirits, or as we say, ' in fun,' and may easily give rise to mockery. I have witnessed examples enough in proof of this, but if I gave them it might be thought that I wished to amuse profane readers ${ }^{2}$. And though such extreme disasters may be exceptional outbursts, yet they are always but just beneath the surface, and are the inevitable outcome of the use of unworthy means. The cause of such a choice of means must be either an artistic incapacity to distinguish, or a want of faith in the power of religious emotion when unaided by profane adjuncts. What would St. Augustin have ruled here, or thought of the confusion of ideas, which, being satisfied with any expression, mistakes one emotion for another?

' Besides, the main fault of these books, from which we should have to quote, is the assaciation of the music, and this is really an accident, the question before us being the charactor of the music; so that we should require musical illustration, for though the common distinction between sacred and secular music is in the main just, yet the line cannot be drawn at the original intention, or historical origin of the music: the true differentiation lies in the character of the music, the associated sentiment being liable to change. If we were to banish from our hymn-books all the tunes which we know to have a secular origin, we should have to part with some of the most sacred and solemn compositions; and where would the purist obtain any assurance that the tunes which he retained had a better title? In the sixteenth century, when so many fine hymn-melodies were written, a musician was working in the approved manner if he adapted a secular melody, or at least borrowed a well-known opening phrase: and since the melodies of that time were composed mainly in conjunct movement, such initial similarities were unavoidable; for one may safely say that it very soon became impossible, under such restrictions, to invent a good opening phrase which had not been used before. The secular airs, too, of that time were often as fit for sacred as profane use; and if I had to find a worthy melody for a good new hymn, I should seek more hopefully among them than in the sacred music of our own century.

- I may give the following experience without offence. When I was an undergraduate there was a song from a comic opera by Offenbach so much in favour as to be de rigurur at festive meetings. Now there was at the same time a counterpart of this song popular at evensong in the churches : it was sung to 'Hark, hark, my soul.' I believe it is called L'mens des feurs. They seemed to me both equally nauseating : it was certainly an accident that determined which should be sung at worship and which at wine. 
The practical question now arises. We know the need; how is it to be supplied? We require music which will reach the emotions of uneducated people, and in which they will delight to join, and in which it shall be easy to join : and it must be dignified and not secular. If we condemn and reject the music which the professional church-musicians have supplied with some popular success to meet the need, what is there to take its place? Of what music is our hymn-book to be constructed, which shall be at once dignified, sacred. and popular?

The answer is very simple: it is this, Dignified Melody. Good melody is never out of fashion; and as it is by all confession the seal of high musical genius, so it is that form of music which is universally intelligible and in the best sense popular; and we have a rich legacy of it. What we want is that our hymn-books should contain a collection of the best ecclesiastical and sacred hymn-melodies, and nothing but these, instead of having but a modicum of these. for the most part mauled and illset, among a crowd of contributions of an altogether inferior kind; the whole collection being often such that if an illnatured critic were to assert that the compilers had degraded and limited the old music in order to set off their own, it would be difficult to meet him with a logical refutation.

The shortest and most practical way of treating this subject will be to give some account of the sources from which the music of such a hymn-book as I propose would be drawn. I will take these in their chronological order. First in order of time are the Plain-song melodies.

I have already stated the ordinary objection to these tunes, that they are stiff and out of date. Now it may be likely enough that they will never be so universally popular in our country as the fine melodies invented on the modern harmonic system, yet the idea that they are not popular in character, and that modern people will not sing them, is a mistake; there is plenty of evidence on this point. Nor must we judge them by the incompetent, and I confess somewhat revolting aspect in which they were offered to us by the Ang!o-gregorianists of thirty years ago, a presentment which has gone far to ruin their reputation; they are better understood now, and may be heard here and there sung as they should be. They are of 
great artistic merit and beauty; and instead of considering them a priori as uncongenial on the ground of antiquity, we should rather be thinking of them that they were invented at a time when unison singing was cultivated in the highest perfection, so much so that a large number of these tunes are, on account of their elaborate and advanced rhythm, not only far above the most intelligent taste of the minds with which we have to deal, but are also so difficult of execution that there are few trained choirs in the country that could render them well. To the simpler tunes, however, these objections do not apply : in fact there are only two objections that can be urged against them, and both of these will be found on examination to be advantages.

The first objection is that they are not in the modern scale. Now as this objection is only felt by persons who have cramped their musical intelligence by an insufficient technical education, and cannot believe that music is music unless they are modulating in and out of some key by means of a sharp seventh ; - and as the nature of the ecclesiastical modes is too long a subject, and too abstruse for a paper of this sort, even if I were competent to discuss it; - I shall therefore content myself by stating that the ecclesiastical modes have, for melodic purposes (which is all that we are considering), advantages over the modern scale, by which they are so surpassed in harmonic opportunities. Even such a thoroughgoing admirer of the modern system as Sir Hubert Parry writes on this subject, that it 'is now quite obvious that for melodic purposes such modes as the Doric and Phrygian were infinitely (sic) preferable to the Ionic,' i.e. to our modern major keys ${ }^{1}$. And it will be evident to every one how much music has of late years sought its charm in modal forms, under the guise of national character.

The second objection is their free rhythm. They are not written in barred time, and cannot without injury be reduced to it.

As this question affects also other classes of hymns, I will here say all that I have to say, or have space to say, about the rhythm of hymn-tunes; confining my remarks generally to the proper dignified rhythms.

In all modern musical grammars it is stated that there are

1 The Art of Ancic, by C. Hubert H. Parry. London, 1893, ist edit, p. 48. 
virtually only two kinds of time. The time-beat goes either by twos or some multiple of two, or by threes or some multiple of three, and the accent recurs at regular intervals of time, and is marked by dividing off the music into bars of equal length. Nothing is more important for a beginner to learn, and yet from the point of view of rhythm nothing could be more inadequate. Rhythm is infinite. These regular times are no doubt the most important fundamental entities of it, and may even lie undiscoverably at the root of all varieties of rhythm whatsoever, and further they may be the only possible or permissible rhythms for a modern composer to use, but yet the absolute dominion which they now enjoy over all music lies rather in their practical necessity and convenience (since it is only by attending to them that the elaboration of modern harmonic music is possible), than in the undesirability (in itself) or unmusical character of melody which ignores them. In the matter of hymn-melodies an unbarred rhythm has very decided advantages over a barred rhythm. In the former the melody has its own way, and dances at liberty with the voice and sense; in barred time it has its accents squared out beforehand, and makes steadily for its predetermined beat, plumping down, as one may say, on the first note of every bar whether it will or no. Sing to any one a plain-song melody, Ad coenam Agni for instance, once or twice, and then Croft's $14^{8}$ th Psalm ${ }^{1}$. Croft will be undeniably fine and impressive, but he provokes a smile: his tune is like a diagram beside a flower.

Now in this matter of rhythm our hymn-book compilers, since the seventeenth century, have done us all a vast injury. They have reduced all hymns to the common times. Their procedure was, I suppose, dictated by some argument such as this: 'The people must have what they can understand : they only understand the simple two and three time: crgo we must reduce all the tunes to these measures.' Or again, 'It will be easier for them to have all the tunes as much alike as possible: therefore let us make them all alike, and write them all in equal minims.'

Both these ideas are absolutely wrong. A hymn-tune, which they hastily assume to be the commonest and lowest form of

1 And give Croft the advantage of his original rhythm, not the mis-statement in Hymis Anciont and Hodem, No. $4^{14}$. 
music actually possesses liberties coveted by other music ${ }^{1}$. It is a short melody, committed to memory, and frequently repeated: there is no reason why it should submit to any of the time-conveniences of orchestral music: there is no reason why its rhythm should not be completely free; nor is there any a priori necessity why any one tune should be exactly alike another in rhythm. It will be learned by the ear (most often in childhood), be known and loved for its own sake, and blended in the heart with the words which interpret it: and this advantage was instinctively felt by those of our early church composers who, already understanding something of the value of barred music, yet deliberately avoided cramping the rhythms of their hymn-tunes by too great subservience to it ${ }^{2}$. One of the first duties therefore which we owe to hymn-melodies is the restoration of their free and original rhythms, keeping them as varied as possible: the Plain-song melodies must be left unbarred and be taught as free rhythms, and all other fine tunes which are worth using should be preserved in their original rhythm; because free rhythm is better, and its variety is good, and because the attraction of a hymn-melody lies in its individual character and expression, and not at all in its time-likeness to other tunes. This last idea has been a chief cause in the degradation of our hymns.

I may conclude then that the best of these simpler Plain-song tunes are very fit for congregational use. They should be offered as pure melody in free rhythm and sung in unison: their accom-

I It would be very demaging to my desire to convince, if I should seem to deny that the mistaken practice of these hymn-book compilers was based on the solid ground of secular common-sense. If anything is true of rhythm it is this, that the common mind likes common rhythms, such as the march or waltz, whereas elaboration of rhythm appeals to a trained mind or artistic faculty. I should say that the popularity of common rhythms is due to the shortness of human life, and that if men were to live to be 300 yearg old they would weary of the sort of music which Robert Browning describes so well-

'There's no keeping one's haunches still,

There's no such pleasure in life.'

But hymn-melodies must not be put on that level. It is desirable to have in church something different from what goes on outside, and (as I say in the text) a hymntune need not appeal to the lowest understanding on first hearing. The simple free rhythms, too, are perfectly natural ; they were free-born.

'I need only instance Orlando Gibbons' tune called 'Angels.' The original is a most ingenious combination of thythms; and its masterly beauty could not be guessed from the inane form into which it is degraded in Hymm Anciont and Modem, No. 8. 
paniment must not be entrusted to a modern grammarian. It is well also to use most of them in their English form, the Old Sarum Use as it is called; which happily preserves to us a national tradition, in the opinion of some experts older and more correct than any known on the continent; and if the differences in our English version are not due to purity of tradition, they will have another and almost greater interest, as venerable records of the genius of our national taste. These Plain-song tunes have probably a long future before them ; since, apart from their merit, they are indissolubly associated with the most ancient Latin hymns, some of which are the very best hymns of the Church.

The next class of tunes ${ }^{1}$ is that of the REFORMATION hymns, English, French, and German, dating from about $155^{\circ}$ to some way on in the seventeenth century. The chief English group is known as Sternhold and Hopkins' Psalter, which was mostly of eight-line tunes. This book was virtually put together in Geneva about 1560 , and antiquarians make much of it. If stripped, however, of its stolen plumes and later additions it is really an almost worthless affair, the true history of it being as follows. A French musician named Louis Bourgeois, whom Calvin brought with him to Geneva in $154 \mathrm{I}$, turned out to be an extraordinary genius in melody; he remained at Geneva about fifteen years, and in that time compiled a Psalter of eighty-five tunes, almost all of which are of great merit, and many of the very highest excellence. The splendour of his work, which was merely appreciated as useful at the time, was soon obscured, for immediately on his leaving Geneva, the French Psalter was completed by inferior hands, whose work, being mixed in with his, lowered the average of the whole book enormously, and Bourgeois' work was never distinguished until, quite lately, the period of his office was investigated and compared with the succeeding editions of his book. Now the English refugees compiled their 'Sternhold and Hopkins' at Geneva, in imitation of the French, during the time of Bourgeois' residence, and took over a number of the French tunes; though they mauled these most unmercifully to bring them down to the measure of their

1 I omit, for want of space, mention of the late Plain-song melodies (which would give a good many excellent tunes); and for want of knowledge the Italian tunes. 
doggerel psalms, yet even after this barbarous treatment Bourgeois' spoilt tunes were still far better than what they made for themselves, and sufficient not only to float their book into credit, but to kindle the confused enthusiasm of subsequent English antiquarians, whose blind leadership has had some half-hearted following. But if these French tunes, and those which are pieced in imitation of Bourgeois, be abstracted from this English Psalter, then, with one or two exceptions, there will remain hardly anything of value ${ }^{1}$.

To leave the English tunes for a moment and continue the subject, we shall practically exhaust the French branch of this class by saying that our duty by them is to use a great number of Bourgeois' tunes, restoring their original form. They are masterpieces which have remained popular on the continent from the first; thoroughly congenial to our national taste, and the best that can be imagined for solemn congregational singing of the kind which we might expect in England. The difficulty is the same that beset the old original psalter-makers, i.e. to find words to suit their varied measures. But this must be done ${ }^{8}$. These tunes in dignity, solemnity, pathos, and melodic solidity leave nothing to desire.

' Comparing the English with the French Genevan Psalter, I do not think my judgement is too severe on our own. It had a few fine tunes original to it; best of all the crovii (degraded in Hymms Anciont and Hadom). This is of such exceptional beauty that I believe it must heve been written by Bourgeois for Whittingham. Next perhaps is lxrvii (called 81st in $H . A . M$.), the original of which, in Day, ${ }^{566}$, is a fine tune, degraded already in Este, $159^{2}$, which version $H$. A.M. follows : it is said to have come from Genera. Besides these, urv and rliv, which are the only other tunes from this source in $H$. A. H., are very favourable examples, and I do not think that they will rescuc the book. Nor can I believe that these old English D.C.M. tunes were ever much used. They are too much alike for many of them to have been committed to memory, while all the editions which I happen to have seen are full of misprints, and the four-line tunes which drove them out were early in the field, and increased rapidly.

- When one turns the pages of that most depressing of all books ever compiled by the groaning creature, Julian's bymn-dictionary, and sees the thousands of carefully tabulated English hymns, by far the greater number of them not only pitiable as efforts of human intelligence, but absolutely worthless ag vocal material for melodic treatment, one wishes that all this effort had been directed to supply a real want. E. g. the two Wesleys between them wrote thirteen actavo volumes, of some 400 pages each, full of closely printed hymons. One must wish that Charles Wesley at least (who showed in a few instances how well he could do) had, instead of reeling off all this stuff, concentrated his efforts to produce only what should be worthy of his tolents and useful to posterity. 
The English eight-line tunes of Sternhold and Hopkins we may then, with one or two exceptions, dismiss to neglect ; but among the four-line 'common' tunes which gradually ousted them, there are about a dozen of high merit : these being popular still at the present day require no notice, except to insist that they should be well harmonized in the manner of their time, and generally have the long initials and finals of all their lines observed. They are much finer than any one would guess from their usual dull presentment. Their manner, as loved and praised by Burns, is excellent, and there is no call to alter it .

Contemporary with this group there is a legacy of a dozen and more fine tunes composed by Tallis and Orlando Gibbons, the neglect or treatment of which is equally disgraceful to all concerned.

As for the German tunes of the Reformation, attempts to introduce the German church-chorales into anything like general use in England have never, so far as I know, been successful, owing, I suppose, to a difference in the melodic sense of the two nations. But some few of them are really popular, and more would be if they were properly presented with suitable words; and it should not be a difficult task to provide words even more suitable and kind than the original German, which seldom observes an intelligent, dignified and consistent mood. These chorales should be sung very slow indeed, and will admit of much accompaniment. Bach's settings, when not too elaborate or of impossible compass in the parts, may be well used where the choir is numerically strong. He has made these chorales peculiarly his own, and, in accepting his interpretation of them, we are only acquiescing in a universal judgement, while we make an exception in favour of genius; for as a general rule (which will of course apply to those chorales which we do not use in Bach's version), all the music of this Reformation period must be harmonized strictly in the vocal counterpoint which prevailed at the end of the sixteenth century; since that is not only its proper musical interpretation, but it is also the ecclesiastical style par excellence, the field of which may reasonably be extended, but

2 If old tones are modernized out of a fine rhythm, a curious result would be likely to come about; vix. that modern tunes might be written in the old rhythm for the sake of novelty, while the old were being sung in the more modern way for the sake of uniformity. 
by no means contracted. It is suitable both for simple and elaborate settings, for hymns of praise or of the more intimate ideal emotions, and in a resonant building a choir of six voices can produce complete effects with it. The broad, sonorous swell of its harmonious intervals floods the air with peaceful power, very unlike the broken sea of Bach's chromatics, which, to produce anything like an equal effect of sound, needs to be powerfully excited.

It is necessary to insist strongly on one caution, viz. that grammar is not style, and settings which avoid modernisms are not for that reason a fair presentation of the old manner. Nothing is less like a fine work of art than its incompetent imitation. And this practically exhausts, as far as I am aware, the material which this period provides.

The next class will be made up of our RESTORATION hymns, by Jeremy Clark, Croft, and others who added to the succeeding editions of the metrical Psalms. If there are not many in this class, yet the few are good ; and Clark must be regarded as the inventor of the modern English hymn-tune, regarded, that is, as a pure melody in the scale with harmonic interpretation of instrumental rather than true vocal suggestion. His tunes are pathetic, melodious, and of truly national and popular character, the best of them almost unaccountably free from the indefinable secular taint that such qualities are apt to introduce, and which the bad following of his example did very quickly introduce in the hands of less sensitive artists. They are suitable for evening services.

After this time there followed in England, in the wake of Handel, a degradation of style which is now completely discredited. Diatonic flow, with tediously orthodox modulation, overburdened with conventional graces, describe these innumerable and indistinguishable productions. And just as the old tunes were related to the motets and madrigals, so are these to the verse-anthems and glees of their time. These weak ditties, in the admired manner of Lord Mornington, were typically performed by the genteel pupils of the local musician, who, gathered round him beneath the laughing cherubs of the organ case, warbled by abundant candlelight to their respectful audience with a graceful execution that rivalled the weekday performances of Celia's Arbour and the Spotted Snakes. Good 
tunes may be written at any time, for style is independent of fashion; but there are very few exceptions to the complete and unregretted disappearance of all the tunes of this date.

We have then nothing left for us to do but to review the material which the revival of music in the last fifty years has given us in the way of hymns.

This last group divides naturally into two main heads; first the restoration of old hymns of all kinds, with their plain, severer manner, in reaction against the abused graces; and secondly the appearance of a vast quantity of new hymns.

Concerning the restoration of the old hymns, we cannot be too grateful to those who pointed the right way, and, according to their knowledge and the opportunities of the taste of their day, did the best that they could. But, as our remarks under the heads of Plain-song and Reformation hymns will show, this knowledge, taste, and opportunity were insufficient, and all their work requires to be done afresh.

We are therefore left to the examination of the modern hymns. In place of this somewhat invidious task, I propose to make a few remarks on the general question of the introduction of modern harmony into ecclesiastical music, with reference of course to hymns only. It cannot escape the attention of any one that the modern church music has for one chief differentiation the profuse employment of pathetic chords, the effect of which is often disastrous to the feelings.

Comparing a modern hymn-tune in this style with some fine setting of an old tune in the diatonic ecclesiastical manner, one might attribute the superiority of the old music entirely to its harmonic system; but I think this would be wrong.

It is a characteristic of all early art to be impersonal ". As long as an art is growing, artists are engaged in rivalry to develop the new inventions in a scientific manner, and individual personality is not called out. With the exhaustion of the means in the attainment of perfection a new stage is reached, in which individual expression is prominent, and seems to take the place of the scientific impersonal interest which aimed at nothing but

1 This fact is of course generally recognized. The explanation in the text is one which was elaborately illustrated by the Slade Professor at Oxford, in his last course of lectures on painting. 
beauty: so that the chief distinction between early and late art is that the former is impersonal, the latter personal.

Turning now to the subject of ecclesiastical music, and comparing thus Palestrina with Beethoven or Mozart, is it not at once apparent that Palestrina has this distinct advantage, namely, that he seems not to interfere at all with, or add anything to, the sacred words? His early musical art is impersonal, what the musicians call 'pure music'; and if he is setting the phrases of the Liturgy or Holy Scriptures, we are not aware of any adjunct; it seems rather as if the sacred words had suddenly become musical. Not so with Mozart or Beethoven; we may prefer their music, but it has interfered with the sacred words, it has, in fact, added a personality.

It must of course be conceded that this gives a very strong if not logically an almost unassailable position to those who would confine sacred music to the ecclesiastical style. But it seems to me ridiculous to suppose that genius cannot use all good means with reserve and dignity; and if the modern church music will not stand comparison in respect of dignity and solemnity with the old, the fault must rather lie in the manner in which the new means are used, than in the means themselves; nor would I myself concede that there is no place in church for music which is tinged with a human personality; I should be rather inclined to reckon the great musicians among the prophets, and to sympathize with any one who might prefer the personality of Beethoven (as revealed in his works) to that of a good many canonized seers. What is logical is that we should be careful as to what personality we admit, and see that the modern means are used with reserve.

Now if we examine our modern hymn-tunes, do we find any sign of that reserve of means which we should expect of genius, or any style which we could attribute to the personality of a genius? Let any one in doubt try the following experiment : copy out some 'favourite tune' in the 'admired manner' of the present day, and show it to some musician who may happen not to know it, and ask him if it is not by Brahms; then see how he will receive any further remarks that you may make to him on the subject of music.

These new tunes are in fact, for the most part, the indistin- 
guishable products of a school given over to certain mannerisms, and might be produced ad libitum, as indeed they are; just as were the tunes of the Lord Mornington school before described : and though the composers and compilers of these modern tunes would be the first to deride the exploded fashion, their own fashion is more foolish, and promises to be as fugitive 1 .

I have said very little in this essay on the words of hymns. I will venture to add one or two judgements here. First, that in the Plain-song period, words and music seem pretty equal and well matched. Secondly, that in the Reformation period, and for some time onwards, the musicians did far better than the sacred poets, and have left us a remainder of admirable music, for which it is our duty to find words. Thirdly, that the excuse which some musicians have offered for the sentimentality of these modern tunes, namely, that the words are so sentimental, is not without point as a criticism of modern hymn-words, but is of no value whatever as a defence of their practice. The interpretative power of music is exceedingly great, and can force almost any words (as far as their sentiment is concerned) into a good channel.

And if music be introduced at all into public worship it must be most jealously and scrupulously guarded. It is a confusion of thought to suppose that because-as St. Augustin would tell us-it is not a vital matter to religion whether it employ music or not, therefore it can be of little consequence what sort of music is used: and the attitude of indifference towards it, which has seemed to me to be almost a point of correct ecclesiastical manners, must be the expression of a convinced despair, which, in the present state of things, need not surprise. Devout persons are naturally afraid of secular ideals, and shrink from the notion of art intruding into the sanctuary; and, especially if they have never learned music, they will share St. Augustin's jealousy of it ; and it is the more difficult to remove their objections, when

1 There is one point which I cannot pass over. It has become the practice in modern books to put marks of musical expression to the words, directing the congregation when to sing loud or soft. This implies a habit of congregational performance the description of which would make a companion picture to the organ gallery of 1830 . It seems to me a practice of inconceivable degradation : one asks in trembling if it is to be extended to the Psalms. It is just as if the congregation were school-children singing to please a musical inspector, and he a stupid one. 
what they are innocently suffering in the name of art curdles the artist's blood with horror, and keeps him away from church. The artist too, to whom we might look for help, is the rara avis in terris, and, in regard to his sympathy with the clergy, would often be thought by them to deserve the rest of the hexameter; but it is really to his credit that he is loth to meddle with church music. Its social vexations, its eye to the market, its truckling to vulgar taste and ready subservience to a dominant fashion, which can never (except under the rarest combination of circumstances) be good;-all this is more than enough to hold him off. Where then is the appeal? Quis custodiet?

The unwillingness of the clergy ${ }^{1}$ to know anything about music might be got over if the music could be set on a proper basis; and in the present lack of authority and avowed principles, it would be well if such of our cathedral precentors and organists as have the matter at heart would consult and work together with the purpose of instructing pastors and people by the exhibition of what is good. This is what we might expect of our religious musical foundations, which are justifying the standing condemnation of utilitarian economists so long as the stipendiaries are content indolently to follow the fortuitous traditions of the books that lie in the choir, supplemented by the penny-a-sheet music of the common shops. In the Universities, too, it should be impossible for an undergraduate not to gain acquaintance with good ecclesiastical music, and this is not ensured by an occasional rare performance of half a dozen old masterpieces which are preserved in heartless compliment to antiquity. It is to such bodies that we must first look for help and guidance to give our church music artistic importance : for let no one think that the church can put the artistic question on one side. There is no escape from art ; art is only the best that man can do, and his second, third, fourth or fifth best are only worse efforts in the same direction, and in proportion as they fall short of the best the more plainly betray their artificiality. To refuse the best for the sake of something inferior of the same kind can never be

1 It must be due to unwillingness that comparatively so few of our clergy can take their part in the service when it is musical. Village schoolmasters tell me that two hours a week is sufficient in a few months to bring all the children up to a standard of time and tune and reading at sight that would suffice a minor canon. 
a policy; it is rather an uncorrected bad habit, that can only be excused by ignorance; and ignorance on the question of music is every day becoming less excusable; and the growing interest and intelligence which all classes are now showing should force on religion a better appreciation of her most potent ally. Music being the universal expression of the mysterious and supernatural, the best that man has ever attained to, is capable of uniting in common devotion minds that are only separated by creeds, and it comforts our hope with a brighter promise of unity than any logic offers. And if we consider and ask ourselves what sort of music we should wish to hear on entering a church, we should surely, in describing our ideal, say first of all that it must be something different from what is heard elsewhere; that it should be a sacred music, devoted to its purpose, a music whose peace should still passion, whose dignity should strengthen our faith, whose unquestioned beauty should find a home in our hearts, to cheer us in life and death; a music worthy of the fair temples in which we meet, and of the holy words of our liturgy; a music whose expression of the mystery of things unseen never allowed any trifling motive to ruffle the sanctity of its reserve. What power for good such a music would have!

Now such a music our Church has got, and does not use; we are content to have our hymn-manuals stuffed with the sort of music which, merging the distinction between sacred and profane. seems designed to make the worldly man feel at home, rather than to reveal to him something of the life beyond his knowledge : compositions full of cheap emotional effects and bad experiments made to be cast aside, the works of the purveyors of marketable fashion, always pleased with themselves, and always to be derided by the succeeding generation ?

\section{ROBERT BRIDGES.}

1 Example is better than precept; and my own venture as a compiler of a hymnbook has made it possible for me to say much that otherwise I should not have said. In The Yattendon Hymnal, printed by Mr. Horace Hart at the Clarendon Press, Oxford, and to be had of Mr. Frowde, price 20s., will be found a hundred hymns with their music, chosen for a village choir. The music in this book will show what sort of a hymnal might be made on my principles, while the notes at the end of the volume will illustrate almost every point in this essay which requires illustration, besides many others. As I write, the last sheets of it are in the press, and the printer promises it in October. 